\title{
Identifying Challenges in the Field of Performance and Providing Strategies for Strengthening Local Learning Centers of the Literacy Movement: A Case Study of Hormozgan Province
}

\author{
Mokhtar Zakeri*1, Mahmood Sabahizadeh ${ }^{2}$
}

1. Assistant Professor, Department of Educational Sciences, Farhangian University, Tehran, Iran.

2. Assistant Professor, Department of Educational Sciences, Bandar Abbas Branch, Islamic Azad University, Bandar Abbas, Iran.

* Corresponding author's Email: mokhtarzakeri@yahoo.com

\begin{abstract}
In this study, it was sought to identify challenges in the field of performance and provide solutions to strengthen the local learning centers of the literacy movement in Hormozgan province. For this purpose, the qualitative research method of inductive analysis with data coding system was used. The research population consisted of experts, educators and literacy students of the literacy movement of Hormozgan province, (1320 people) and a sample of twenty-five people who were selected using purposive sampling method. Data collection tool was in-depth interview and data analysis method was inductive analysis. Findings indicated that the functional challenges of local learning centers in Hormozgan province fall into three categories: organizational harms including communication, quality of work life and organizational information technology; motivational harms including human characteristics, lack of empowerment and lack of staff training and environmental harms including political, economic, social, environmental, information technology and outside the organization factors. Strengthening the cognitive and skill level of the audience and stakeholders of the project, improving the economic level of the project audience, improving the time period for educating new learners and improving the level of social support for literacy were the four key categories opportunities for advancing local learning centers. Strengthening the cognitive and skill level of the audience and project stakeholders had the highest frequency among them. Upgrading the use of technology, upgrading the executive infrastructure and upgrading the level of supervision are ways to strengthen the level of local learning centers. Strengthening the level of participation of individuals and institutions related to the project, improving the level of motivation of individuals and related institutions and improving the quantity and quality of educational fields had the highest frequency among them.
\end{abstract}

Keywords: Pathology, Functional Challenges, Local Learning Centers, Literacy Movement

\section{Introduction}

Literacy is considered as a basic strategy in promoting physical, mental and social health. Literacy plays an important role in strengthening the sense of social responsibility, decision-making power and initiative and increasing self-confidence. People who have not been able to use an adequate and timely educational system due to existing limitations, they can have a sense of adequacy, value and competence and be more successful in personal and social life through literacy. Literacy and adult education are important in development efforts (Barghi, 2018).

The main policy for lifelong learning is to provide access to education for all learners. Therefore, in order to achieve lifelong learning among the illiterate in 1985, the plan to establish local learning centers in the world was approved by the 23rd Conference of UNESCO Ministers of Education, which was held at the UNESCO Regional Conference in Sofia, Bulgaria. It was adopted in 1987 as a recommendation 
of the Fifth Conference of Asia-Pacific Ministers of Education and Economic Planning in India to be implemented in member countries. Subsequently, the plan to establish local learning centers in AsiaPacific in 1995 in the implementation of the education program for all was implemented by the UNESCO Regional Office in 18 countries (Pirian, 2012).

The local learning center is an educational unit based on local needs assessment and in order to provide educational services to illiterate and low literacy people, including basic literacy training, basic life skills training, citizenship rights and social skills to empower and create opportunities for lifelong learning using the existing capacities in coordination with the Education Council of province (Hadianfard, 2019). Despite the efforts made in recent years, one of the problems in our society, especially in the literacy community of the literacy movement, is the neglect of the local learning centers of the literacy movement. The educational goals of these centers have not been achieved in practice as well. In this regard, researchers seek to understand the challenges of advancing these centers and, consequently, the opportunities and strategies to strengthen these centers.

There is no doubt about the effectiveness of training, but to conduct effective education, it is necessary for countries to adapt to complex conditions to deal with changes logically and move their organizations towards success. Therefore, in order to study the factors affecting the effectiveness of education, more studies on needed on how to prepare the platform for education, analysis of educational needs, evaluation, monitoring and improvement of the educational process and how to educate illiterate and low literacy adults to increase their effectiveness in countries (Eskandari, 2015). Accordingly, this study investigated this issue with regard to the local learning centers of the literacy movement.

Today, most countries hold several training courses in their training centers or learning centers, and the implementation of each course involves a huge investment and time spent serving active manpower. But, it is very important for managers to know the effectiveness of training courses and their efficiency. Determining the effectiveness of trainings helps planners and managers to have a clear picture of the performance of training and to design specific, required, complementary and directional trainings instead of designing general and overall courses. This evaluation also identifies the strengths, shortcomings and methods of its development and correction and the extent to which the goals are achieved, and generally provides an overview of the effectiveness of the educational process. Since learning is one of the most important achievements of the educational system and due to the importance of identifying the necessary conditions for training qualified people in literacy learning centers, and the importance of functional challenges in this area, in the current study, it was sought to identify these challenges and help strengthen local learning centers in Hormozgan province by providing solutions.

Little research has been done in Iran regarding the literacy movement and especially local learning centers. Here are some of these studies. Rahiminejad (2012) in his study entitled 'Comparative study of the adult education system in the world and providing the axes of an efficient and effective model for the adult education system' indicated that are necessary in adult education programs to change the target community from the illiterate to the low literacy and literate one, and accordingly to promote the 
definition of literacy with social and cultural capacities, and focus on policies for educating the illiterate in urban areas, especially suburbs.

Pyrian (2012) in a study entitled 'the effect of educators 'psychological literacy on literacy students' desire to participate in literacy courses' concluded that in the issue of literacy, addressing motivation is necessary because the planners want to lead the illiterate person to development. Educators can motivate illiterate people with sufficient, comprehensive and up-to-date knowledge.

Hakimzadeh, et al. (2015), in investigating the reasons for not accepting literacy programs in Iran, referred to the components of responsibility, motivation, tuition fees, organizational rules, linguistic issues, course purpose, literacy awareness, accommodation, facilities and schedule, job and family issues and awareness of literacy programs. From the educators' point of view, some components including course purpose, facilities and schedule, course compliance with adult learning principles, evaluation and feedback, content, support, linguistic issues, organizational rules and accommodation were considered.

Mohseni and Hosseini (2016) considered challenges in the transfer of activities, recruitment and specialization of trainers, training and promotion of professional qualifications of trainers, salaries and payments, and identification and recruitment of learners as harms of human resource management.

Sadeghpour (2016), in a study entitled 'Study of the causes of illiteracy in the primary literacy classes from the perspective of educators of the East Tehran Literacy Movement' considered the lack of knowledge about literacy activities, life concerns and lack of mastery of teaching as the reasons of not accepting the literacy.

Teymourian (2016), in comparing active teaching methods between literacy movement instructors and graduates of teacher training centers in the elementary school of Abdanan city, indicated the knowledge and awareness of teachers graduating from teacher training centers with the principles and techniques of active teaching methods was greater than instructors of the literacy movement. There was no significant relationship between gender, years of service and the level of awareness of teachers in both groups about the principles and techniques of active teaching methods. The findings also indicated that most teachers who have previously served as educators in the literacy movement are not familiar with active teaching methods.

Findings of Hadianfard' s (2019) study on people's attitudes about public participation in the implementation and development of adult literacy indicated that women compare to men and the elite group compared to the normal group significantly considered participation in literacy as a necessary issue. The study generally revealed that people use inefficient belief, such as society needs illiterate people to do hard work, justified their non-participation. These dysfunctional beliefs seemed to be influenced by the existence of unemployed university graduates at the community.

Zakeri and Sabahizadeh (2016), in a study entitled identifying the challenges and strategies for improving the family literacy plan, concluded that there are eight central categories in the harms of the plan including the lack of financial resources, weak monitoring system, weak content, lack of comprehensiveness of the plan, weakness of project stakeholders, incompatibility of the plan with 
influential factors, weak motivation and lack of adequate institutional media support. Consequently, eight components of financial support including strengthening the evaluation and monitoring system of the project, developing the attitude and training of project stakeholders, strengthening the staff system and scope of the project, strengthening the motivational dimension, strengthening institutional and media support of the project could improve reading plan in the family.

Collins (2011) conducted a study aimed at identifying motivational factors and barriers to adult participation in training courses. This research examined situational, organizational, tendency barriers, and internal and external motivational factors. The results of this study revealed that the distance between home and school, the cost of courses and not knowing what to learn were the main barriers to participation. Career development and major life events have also played a key role in motivating adults to participate and attend training courses.

Kurt et al. (2018), in a study entitled 'Education and Productivity in Turkey', examined the relationship between education and productivity in educational organizations of Turkish learning centers and concluded that attention to education and educational needs have been manifested in different ways in educational organizations. They believed that the development and dissemination of information and training could greatly contribute to productivity in organizations.

According to the findings of Pozdenikova (2019), an average increase of 20 to 30 percent in literacy causes an increase of 8 to 16 percent in GDP. In general, the functions of literacy are manifested in various social, cultural, economic and even political aspects. Accordingly, in many EU member states, high quality adult education is an important goal and a significant decision. In fact, adults learn and teach in different educational ways. Also, in order to optimize education and learning, various methods and techniques are used including coping with anxiety, acquiring learning skills and family support.

A critical review of the research background indicates that despite issues such as challenges and strategies to improve the family literacy plan, teaching methods in literacy courses, motivational factors and barriers to adult education participation, education and productivity and literacy, the impact of psychological literacy and comparative studies in the field of literacy in some studies, but in general, no specific research has been done on the subject of this research.

The main purpose of this research was to identify the challenges in the field of performance and to provide solutions to strengthen the local learning centers of the literacy movement. Hence the research questions are:

1. What are the challenges in the field of performance of local learning centers in Hormozgan province?

2. What are the learning opportunities for learners of local learning centers in Hormozgan province?

3. What are the strategies to strengthen local learning centers in Hormozgan province? 


\section{Material and Methods}

The research method was qualitative with an inductive analysis data coding system. The research population included all experts and instructors of the literacy movement in Hormozgan province, whose number was 1320 according to available statistics, and the sample consisted of twenty-five people who were selected using purposive sampling. The researchers have used the principles of sampling with maximum diversity and saturation. The data interpretation approach in this study was descriptive and interpretive. The researchers collected the data through interviews, and interpreted and categorized them. Hence, the authors do not intend to theorize about the interpretive-abstract approach. Data collection tool was in-depth interview and data analysis method was inductive analysis based on the foundation data coding system, for the first question. Data analysis was done using open, axial and selective coding method. Open coding involves breaking, comparing, conceptualizing, and categorizing data. The first text or data to be obtained should be open-coded as key points. A set of concepts, categories, attributes, and subcategories is the output of the open coding phase. The relationship between each category and its subcategories (not the relationship between categories) takes place in the axial coding phase. The nature of axial coding is the identification of a category, the circumstances that give rise to that category, the context in which the category is located, the strategies for controlling and monitoring that category, and the consequences of those strategies. The process of open and axial coding leads to the emergence of a set of categories that have a specific pattern of relationship between each category and its subcategories. In the next step, the categories are connected and a special theoretical system is presented. Linking categories together is called selective coding. The analysis method for the second and third questions was inductive analysis with coding system. In fact, the three stages of open, axial and selective coding, like the first question, have been done on the second and third questions of the research. To strengthen the research, two criteria of reliability and credibility were used. The interview was conducted in a semi-structured manner after the questions were approved by the senior experts of the Education office and experts in the field of literacy movement and in accordance with the executive instructions of the local learning centers plan. To increase the validity of the research, the results of the analysis of a number of interviews were provided to a number of participants in the research and their opinions were applied to correct some cases. Also, the results of the analysis and review were summarized and the necessary corrections were made after applying the opinions of three experts in the field of literacy movement in the province. The research design was an emerging or exploratory design because the components are not known in advance (Mikat 1994,).

\section{Results}

In answering the first research question about design challenges, by analyzing the text of the interviews and after three coding steps, the following tables were obtained. Each of the following tables is derived from a coding step. 
Open coding phase: The results of open coding phase were presented in the table 1 .

Table 1. Open coding phase from the point of view of experts, educators and literacy movement principals

\begin{tabular}{|c|c|c|}
\hline ID & Open codes & $\begin{array}{l}\text { Frequency (based on } 25 \\
\text { interview data) }\end{array}$ \\
\hline A1 & Laws and regulations of the country & 6 \\
\hline A2 & Approvals of ministries and other relevant organizations & 7 \\
\hline A3 & Bad weather & 17 \\
\hline $\mathrm{A} 4$ & Geographical region & 7 \\
\hline A5 & $\begin{array}{c}\text { Inflation } \\
\text { Unemployment and unemployment rates in the community }\end{array}$ & 11 \\
\hline A6 & Inflation & 6 \\
\hline A7 & Sanction & 2 \\
\hline A8 & Lack of suitable space and sufficient facilities for training & 17 \\
\hline A9 & Insufficient allocation of funds & 22 \\
\hline A10 & Lack of community cooperation & 20 \\
\hline A11 & Lack of cooperation between officials and local centers & 19 \\
\hline A12 & Lack of cooperation of literates & 11 \\
\hline A13 & $\begin{array}{c}\text { Advances in technology (introduction of new software to the market or rapid } \\
\text { changes in software versions) }\end{array}$ & 9 \\
\hline A14 & Advances in technology (entry of new hardware into the market) & 5 \\
\hline A15 & Failure to produce e-learning content & 11 \\
\hline A16 & Age & 5 \\
\hline A17 & Gender & 9 \\
\hline A18 & Marital status & 18 \\
\hline A19 & Variety of tasks and skills & 11 \\
\hline A20 & Lack of practical thinking and not being profitable & 16 \\
\hline A21 & Tasks are meaningless (work is not clear from beginning to end) & 9 \\
\hline A22 & Lack of necessary self-confidence and self-confidence & 10 \\
\hline A23 & Lack of independence and relative authority at work & 15 \\
\hline A24 & Lack of feedback on the job & 7 \\
\hline A25 & Lack of scientific and cultural festivals in sports & 14 \\
\hline A26 & Lack of being effective & 10 \\
\hline A27 & Lack of training in the production of electronic educational content & 17 \\
\hline A28 & Lack of practical thinking and not being profitable & 11 \\
\hline A29 & $\begin{array}{l}\text { Lack of development of technical knowledge and skills of employees in the field } \\
\text { of information technology }\end{array}$ & 13 \\
\hline A30 & Lack of training in the production of electronic educational content & 17 \\
\hline A31 & $\begin{array}{l}\text { Lack of accessibility of employees to information and knowledge resources of } \\
\text { the organization }\end{array}$ & 11 \\
\hline A32 & Lack of formal and in-service training in the organization & 6 \\
\hline A33 & Lack of extracurricular training courses & 8 \\
\hline A34 & Lack of access to new educational technologies such as video conferencing & 9 \\
\hline A35 & $\begin{array}{l}\text { Lack of training employees through group interactions in order to be aware of } \\
\text { each other's work }\end{array}$ & 13 \\
\hline
\end{tabular}




\begin{tabular}{|c|c|c|}
\hline A36 & $\begin{array}{l}\text { Lack of awareness of employees about the technologies, work procedures and } \\
\text { structures in which they work }\end{array}$ & 8 \\
\hline A37 & Job insecurity & 10 \\
\hline A38 & High workload & 11 \\
\hline A39 & Impossibility to implement all policies and notification programs & 13 \\
\hline A40 & Lack of necessary incentives from province and country & 11 \\
\hline A41 & Terms and conditions of employment & 9 \\
\hline A42 & Insufficient written communication (letters, notes, reports, instructions, etc.) & 8 \\
\hline A43 & $\begin{array}{l}\text { Lack of adequate oral communication (informal conversations, group } \\
\text { discussions, job exchanges, formal lectures, etc.) }\end{array}$ & 7 \\
\hline A44 & $\begin{array}{l}\text { Lack of adequate non-verbal communication (body parts, body movements, } \\
\text { environmental factors, office design, building architecture, etc.) }\end{array}$ & 11 \\
\hline A45 & Fair and adequate payment & 11 \\
\hline A46 & Safe and hygienic work environment & 19 \\
\hline A47 & Provide opportunities for continuous development and security & 10 \\
\hline A48 & Legalism in the organization & 15 \\
\hline A49 & Social dependence in working life & 9 \\
\hline A50 & The general atmosphere of life & 7 \\
\hline A51 & Social unity and cohesion in the organization & 9 \\
\hline A52 & Development of human capabilities & 5 \\
\hline A53 & Structural complexity (horizontal, vertical, geographical) & 16 \\
\hline A54 & Focus (decision making at high organizational levels) & 16 \\
\hline A55 & Formality (existence of many rules and regulations) & 13 \\
\hline A56 & Organization size & 10 \\
\hline A57 & distribute duties & 12 \\
\hline A58 & Organizational hierarchy & 16 \\
\hline A59 & Incompatibility with the environment & 9 \\
\hline A60 & Failure to achieve the goal & 16 \\
\hline A61 & Lack of integration of organization members & 10 \\
\hline A62 & Lack of legitimacy in the eyes of the people and other organizations & 9 \\
\hline A63 & Lack of creativity and innovation & 20 \\
\hline
\end{tabular}




\begin{tabular}{|l|c|c|}
\hline A64 & No risk & 14 \\
\hline A65 & Not paying attention to detail & 11 \\
\hline A66 & Not paying attention to the results, not the process of doing the work & 10 \\
\hline A67 & Lack of attention to members of the organization & 12 \\
\hline A68 & The effect of decision results on employees & 6 \\
\hline A69 & Pay attention to the team & 7 \\
\hline A70 & Job requirements (type of job, job security, etc.) & 6 \\
\hline A71 & Sustainability (organization's emphasis on maintaining the status quo) & 9 \\
\hline A72 & Role requirements (role conflict and ambiguity) & 17 \\
\hline A73 & personality) & 9 \\
\hline A74 & Office Automation & 9 \\
\hline A75 & Requirements for interaction with others (group pressure, leadership style and & 10 \\
\hline A76 & Plans such as SENAD & 11 \\
\hline A77 & Direct finance (such as: salaries, wages, cash rewards, etc.) & 11 \\
\hline A78 & grants, etc.) & 13 \\
\hline A79 & Indirect finances (such as: different insurances, retirement benefits, training & \\
\hline
\end{tabular}

As it can be seen in the table 1, 79 basic concept codes were extracted and counted from the text of the interviews as open codes, which were mentioned separately and with frequent mention based on the degree of repetition during 25 interviews. In the following, based on the principle of continuous comparison of data and the principle of inferiority, axial codes have been formulated based on open codes.

Axial coding: The results of axial coding phase were presented in the table 2 .

Table 2. Axial coding from the perspective of experts, educators and literacy movement principals

\begin{tabular}{|c|c|c|}
\hline ID & Open codes & Axial codes \\
\hline $\mathrm{A} 1+\mathrm{A} 2$ & $\begin{array}{l}\text { Laws and regulations of the country + approvals of ministries } \\
\text { and other relevant organizations }\end{array}$ & Political factors \\
\hline $\mathrm{A} 3+\mathrm{A} 4$ & $\begin{array}{c}\text { Climate + minimum and maximum temperature in different } \\
\text { seasons and air pollution }\end{array}$ & $\begin{array}{l}\text { Environmental } \\
\text { factors }\end{array}$ \\
\hline $\mathrm{A} 5+\mathrm{A} 6+\mathrm{AA} 8+\mathrm{A} 9+7$ & $\begin{array}{c}\text { Unemployment rate in the society }+ \text { Inflation }+ \text { Sanctions }+ \\
\text { Lack of suitable space and sufficient facilities for education }+ \\
\text { Lack of sufficient credit }\end{array}$ & Economic factors \\
\hline $\mathrm{A} 10+\mathrm{A} 11+\mathrm{A} 12$ & $\begin{array}{l}\text { Lack of cooperation of officials and local centers + Lack of } \\
\text { cooperation of the community + Lack of cooperation of } \\
\text { literates }\end{array}$ & social factors \\
\hline $\mathrm{A} 13+\mathrm{A} 14+\mathrm{A} 15$ & $\begin{array}{c}\text { Advances in technology (introduction of new software to the } \\
\text { market or rapid changes in software versions) }+ \text { Advances in } \\
\text { technology (introduction of new hardware to the market) }+ \\
\text { Lack of production of e-learning content }\end{array}$ & $\begin{array}{l}\text { Information } \\
\text { technology outside } \\
\text { the organization }\end{array}$ \\
\hline $\mathrm{A} 16+\mathrm{A} 17+\mathrm{A} 18$ & Age + Gender + Marriage & $\begin{array}{c}\text { Human } \\
\text { characteristics }\end{array}$ \\
\hline $\begin{array}{c}\mathrm{A} 19+\mathrm{A} 20+\mathrm{A} 21+\mathrm{A} 22+\mathrm{A} 23+ \\
\mathrm{A} 24+\mathrm{A} 25\end{array}$ & $\begin{array}{l}\text { Variety of tasks and skills + Incomprehensibility of tasks } \\
\text { (specificity of work from beginning to end) + Lack of } \\
\text { scientific and cultural festivals of sports + Lack of } \\
\text { independence and relative authority at work + Lack of } \\
\text { feedback in the job }\end{array}$ & Lack of motivation \\
\hline
\end{tabular}




\begin{tabular}{|c|c|c|}
\hline $\mathrm{A} 26+\mathrm{A} 27+\mathrm{A} 28$ & $\begin{array}{l}\text { Lack of feeling effective }+ \text { Lack of training in the production } \\
\text { of electronic educational content }+ \text { Lack of practical thinking } \\
\text { and not profitable }\end{array}$ & $\begin{array}{c}\text { Lack of } \\
\text { empowerment }\end{array}$ \\
\hline $\begin{array}{c}\mathrm{A} 29+\mathrm{A} 30+ \\
\mathrm{A} 31+\mathrm{A} 32+\mathrm{A} 33+\mathrm{A} 34+\mathrm{A} 35+ \\
\mathrm{A} 36\end{array}$ & $\begin{array}{l}\text { Lack of development of knowledge and technical skills of } \\
\text { employees in the field of information technology + Lack of } \\
\text { training in electronic content production + Lack of access to } \\
\text { information and knowledge resources of the organization }+ \\
\text { Lack of formal and in-service training + Out-of-organization } \\
\text { training courses Videoconferencing + training employees } \\
\text { through group interactions to learn about each other's work + } \\
\text { informing employees about the technologies, work procedures } \\
\text { and structures in which they work }\end{array}$ & $\begin{array}{l}\text { Lack of adequate } \\
\text { staff training }\end{array}$ \\
\hline $\begin{array}{c}\mathrm{A} 37+\mathrm{A} 38+ \\
\mathrm{A} 39+\mathrm{A} 40+\mathrm{A} 41\end{array}$ & $\begin{array}{c}\text { Job security }+ \text { high volume of work }+ \text { impossibility of } \\
\text { implementing all policies and notification programs }+ \text { lack of } \\
\text { necessary incentives from Vastan country }+ \text { job conditions } \\
\text { and situation }\end{array}$ & Job characteristics \\
\hline $\mathrm{A} 42+\mathrm{A} 43+\mathrm{A} 44$ & $\begin{array}{l}\text { Lack of written communication (letters, notes, reports, } \\
\text { instructions, etc.) + lack of verbal communication (informal } \\
\text { conversations, group discussions + non-verbal } \\
\text { communication (body parts, body movements, environmental } \\
\text { factors, office design, building architecture, etc.) ‘ }\end{array}$ & connections \\
\hline $\begin{array}{c}+\mathrm{A} 45+\mathrm{A} 46 \\
\mathrm{~A} 47+\mathrm{A} 48+\mathrm{A} 49+\mathrm{A} 50 \\
+\mathrm{A} 52\end{array}$ & $\begin{array}{c}\text { Fair and adequate payment }+ \text { Safe and hygienic work } \\
\text { environment }+ \text { Ensuring the opportunity for growth and } \\
\text { continuous security }+ \text { Legalism in the organization }+ \text { Social } \\
\text { dependence in work life }+ \text { General living space }+ \text { Unity and } \\
\text { social cohesion in the organization }+ \text { Development of human } \\
\text { capabilities }\end{array}$ & $\begin{array}{l}\text { Quality of working } \\
\text { life }\end{array}$ \\
\hline $\begin{array}{c}+\mathrm{A} 53+\mathrm{A} 54+\mathrm{A} 55+\mathrm{A} 56+\mathrm{A} 57 \\
+\mathrm{A} 58\end{array}$ & $\begin{array}{c}\text { Structural complexity (horizontal, vertical, geographical) + } \\
\text { focus (decision making at high organizational levels) + } \\
\text { formality (existence of many rules and regulations) }+ \\
\text { organization size + division of tasks + organizational } \\
\text { hierarchy }\end{array}$ & $\begin{array}{l}\text { Organizational } \\
\text { Structure }\end{array}$ \\
\hline $\begin{array}{c}\mathrm{A} 59+\mathrm{A} 60+ \\
\mathrm{A} 61+\mathrm{A} 62+\mathrm{A} 63+\mathrm{A} 64+\mathrm{A} 65 \\
+\mathrm{A} 66+\mathrm{A} 67 \\
+\mathrm{A} 68+\mathrm{A} 69+ \\
\mathrm{A} 70+\mathrm{A} 71\end{array}$ & $\begin{array}{l}\text { Incompatibility with the environment + Lack of goal + Lack } \\
\text { of integration of members of the organization + Lack of } \\
\text { legitimacy in the eyes of people and other organizations }+ \\
\text { Lack of creativity and innovation + Lack of risk + Lack of } \\
\text { attention to detail + No effect of decision results on } \\
\text { employees + Attention to the team + Ambition of the } \\
\text { members of the organization + Sustainability (emphasis of the } \\
\text { organization on maintaining the status quo) }\end{array}$ & $\begin{array}{l}\text { Organizational } \\
\text { Culture }\end{array}$ \\
\hline$+\mathrm{A} 72+\mathrm{A} 73+\mathrm{A} 74+\mathrm{A} 75$ & $\begin{array}{l}\text { Job requirements (type of job, job security, etc.) + Physical } \\
\text { requirements (heat, office plan, etc.) + role requirements } \\
\text { (conflict and ambiguity in the role) + requirements for } \\
\text { interaction with others (group pressure, leadership style and) }\end{array}$ & $\begin{array}{l}\text { Organizational } \\
\text { stress }\end{array}$ \\
\hline$+\mathrm{A} 76+\mathrm{A} 77$ & Office automation + special plans such as SENAD and .. & $\begin{array}{l}\text { Information } \\
\text { technology enters } \\
\text { the organization }\end{array}$ \\
\hline$+\mathrm{A} 78+\mathrm{A} 79$ & $\begin{array}{c}\text { Direct finance (such as: salaries, wages, cash bonuses, etc.) + } \\
\text { indirect finance (such as: different insurance, retirement } \\
\text { benefits, training grants, etc.) }\end{array}$ & $\begin{array}{c}\text { Service } \\
\text { compensation }\end{array}$ \\
\hline
\end{tabular}

According to Table 2, 17 axial codes related to the challenges of local learning centers were compiled based on the comparison and aggregation of 79 open codes. Next, the researchers performed selective coding based on the principle of induction and by identifying the differences and similarities between the axial codes obtained in the previous step, which is described in the table 3 . 
Selective coding: The results of selective coding phase were presented in the table 3.

Table 3. Selective coding based on the dimensions of harms from the perspective of experts, educators and literacy movement principals

\begin{tabular}{|c|c|}
\hline Selective codes & Axial codes \\
\hline \multirow[t]{5}{*}{ Environmental harms } & Political factors \\
\hline & Economic factors \\
\hline & Social factors \\
\hline & Environmental factors \\
\hline & Information technology outside the organization \\
\hline \multirow[t]{6}{*}{ Motivational harms } & Human characteristics \\
\hline & Lack of motivation \\
\hline & Lack of empowerment \\
\hline & Lack of staff training \\
\hline & Job characteristics \\
\hline & Service compensation \\
\hline \multirow[t]{6}{*}{ Organizational harms } & Communication \\
\hline & Quality of working life \\
\hline & Organizational Structure \\
\hline & Organizational Culture \\
\hline & Organizational stress \\
\hline & Organizational information technology \\
\hline
\end{tabular}

According to Table 3, the three categories of environmental harms, motivational harms, and organizational harms pose challenges for local learning centers. Environmental harm means factors such as minimum and maximum temperature in different seasons and air pollution, unemployment rate and unemployment in society, inflation, sanctions, lack of adequate space and adequate facilities for education and lack of adequate funding, lack of cooperation between officials and local agencies and no production of e-learning content. Motivational harms are caused by factors such as incomprehensibility of duties, lack of sports, scientific and cultural festivals, lack of independence and relative authority at work, lack of feedback in the job, lack of practical thinking and not being profitable. Organizational harms include incompatibility with the environment, failure to achieve the goal, lack of integration of members of the organization, lack of legitimacy in the eyes of people and other organizations, lack of creativity and innovation, lack of attention to members, lack of impact of decision results on employees 
and ambition of members Takes. The two categories of motivational and organizational harms are the most prominent among the selected codes.

In response to the second question of the research on learning opportunities of local learning centers, by analyzing the text of the interviews, the following table was obtained after three coding steps. Each of the following columns comes from a coding step:

Table 4. The process of coding the learning opportunities of local learning centers

\begin{tabular}{|c|c|c|}
\hline Open codes & Axial codes & Selected codes \\
\hline $\begin{array}{l}\text { Empowering learners by participating in vocational training } \\
\text { courses } \\
\text { Learn new skills in learners } \\
\text { Participating in training courses increases the basic life skills } \\
\text { of learners. } \\
\text { It changes the lifestyle of the audience, that is, it empowers } \\
\text { the individual to achieve a wise and purposeful life. } \\
\text { Participation in the activities and ceremonies of the learning } \\
\text { center will improve the educational level of the learners. The } \\
\text { educational level of the learners is improved by the } \\
\text { participation of the novices in the festivals under any title and } \\
\text { from any level. }\end{array}$ & $\begin{array}{l}\text { Empowering project } \\
\text { audiences }\end{array}$ & \multirow[t]{4}{*}{$\begin{array}{l}\text { Strengthen the cognitive } \\
\text { and skill level of the } \\
\text { audience and project } \\
\text { stakeholders }\end{array}$} \\
\hline $\begin{array}{l}\text { Learners become aware of their rights and citizenship rights } \\
\text { in society and reduce harm to themselves and society. } \\
\text { The level of personal and public health and educational skills } \\
\text { in learners is improved }\end{array}$ & $\begin{array}{l}\text { Improving the cognitive } \\
\text { strength of the project } \\
\text { audience }\end{array}$ & \\
\hline $\begin{array}{l}\text { Empowerment of educators is done by using the capacity of } \\
\text { experts in organizations in the field of skills training. }\end{array}$ & \multirow[t]{2}{*}{$\begin{array}{l}\text { Empowering plan } \\
\text { educators }\end{array}$} & \\
\hline $\begin{array}{l}\text { Up-to-date general information and expertise of the center's } \\
\text { managers } \\
\text { Having experienced and active and specialized trainers and } \\
\text { the required budget }\end{array}$ & & \\
\hline $\begin{array}{l}\text { Entrepreneurial spirit is strengthened in learners } \\
\text { Creating an entrepreneurial spirit in learners by allocating the } \\
\text { low interest loans to set up small businesses }\end{array}$ & $\begin{array}{l}\text { Strengthen the } \\
\text { entrepreneurial spirit }\end{array}$ & \multirow[t]{2}{*}{$\begin{array}{l}\text { Improving the economic } \\
\text { level of the project } \\
\text { audience }\end{array}$} \\
\hline $\begin{array}{l}\text { Establishment a contract in the province with technical and } \\
\text { professional centers for training and providing technical } \\
\text { evidence for learners is done } \\
\text { Creating small and high-yield production and economic } \\
\text { cooperatives is done by learners }\end{array}$ & $\begin{array}{l}\text { Strengthen employment } \\
\text { opportunities }\end{array}$ & \\
\hline $\begin{array}{l}\text { No time limit for supplementary education (profession, skills, } \\
\text { etc.) to the time of literacy classes } \\
\text { Learner and the audience of local learning centers have } \\
\text { unlimited opportunities for the necessary training in the } \\
\text { centers }\end{array}$ & Increase the training time & $\begin{array}{l}\text { Improving the training } \\
\text { period for novices }\end{array}$ \\
\hline $\begin{array}{l}\text { High and continuous support of local learning centers behalf } \\
\text { of governmental offices and With priority the governor }\end{array}$ & $\begin{array}{l}\text { Strengthen the level of } \\
\text { organizational support for } \\
\text { local learning centers }\end{array}$ & $\begin{array}{l}\text { Improving the level of } \\
\text { social support for literacy }\end{array}$ \\
\hline
\end{tabular}


According to Table 4, the four key components including strengthening the cognitive and skill level of the audience and project stakeholders, improving the economic level of the project audience, improving the learning time and improving the level of social support for literacy are the opportunities for local learning centers. Of these four components, the component of strengthening the cognitive and skill level of the audience and project stakeholders has the highest frequency and other components are placed in the next priorities.

In response to the third question of the research on strategies for strengthening local learning centers, the table 5 was coded by analyzing the text of the interviews after three steps. Each of the following columns comes from a coding step:

Table 5. The coding process of strategies to strengthen local learning centers

\begin{tabular}{|c|c|c|}
\hline Open codes & Axial codes & Selected codes \\
\hline $\begin{array}{l}\text { - Cooperation of departments such as the Departments } \\
\text { of Labor, Industry, Mining, Handicrafts, Vocational } \\
\text { Training, Natural Resources and Municipalities }\end{array}$ & $\begin{array}{l}\text { Increase the level of } \\
\text { cooperation within and } \\
\text { between organizations }\end{array}$ & \multirow[t]{3}{*}{$\begin{array}{l}\text { Strengthen the level of } \\
\text { participation of individuals and } \\
\text { institutions related to the project }\end{array}$} \\
\hline $\begin{array}{l}\text { - Close cooperation between local learning center and } \\
\text { administrative devices }\end{array}$ & $\begin{array}{l}\text { Increase the level of social } \\
\text { participation }\end{array}$ & \\
\hline $\begin{array}{l}\text { - Maximum participation of the target community in the } \\
\text { plans and activities of the centers }\end{array}$ & $\begin{array}{l}\text { Increase the level of } \\
\text { organizational participation }\end{array}$ & \\
\hline $\begin{array}{l}\text { - Benefit from the capacity of donors in order to achieve } \\
\text { self-confidence of the target community }\end{array}$ & $\begin{array}{l}\text { Strengthen the motivational } \\
\text { context }\end{array}$ & \multirow[t]{2}{*}{$\begin{array}{l}\text { Improving the motivational } \\
\text { level of individuals and related } \\
\text { institutions }\end{array}$} \\
\hline $\begin{array}{l}\text { - Advertising and promoting the programs and } \\
\text { activities of the centers from the provincial media } \\
\text { Exposing learners' achievements to the public for } \\
\text { promotion in the local community }\end{array}$ & Utilize media capacity & \\
\hline $\begin{array}{l}\text { - Important decisions to improve the goals of the } \\
\text { programs of local learning centers in the meetings of } \\
\text { the Education Council of the cities }\end{array}$ & Holding festivals & \multirow[t]{2}{*}{$\begin{array}{l}\text { Improving the quantity and } \\
\text { quality of educational fields }\end{array}$} \\
\hline $\begin{array}{l}\text { - Giving more privileges to the directors of local } \\
\text { learning centers, even the directors of non- } \\
\text { governmental centers, and expanding the scope of } \\
\text { authority, }\end{array}$ & Holding educational courses & \\
\hline - Providing support and incentive packages for learners & Utilizing technology & Improving the use of technology \\
\hline $\begin{array}{l}\text { - Increasing the per capita local learning } \\
\text { centers and allocating more funds to encourage the } \\
\text { managers of the centers and the training instructors of } \\
\text { the centers. }\end{array}$ & $\begin{array}{l}\text { Strengthen } \\
\text { administrative basis of } \\
\text { project }\end{array}$ & $\begin{array}{l}\text { Upgrading the executive bases } \\
\text { of the project }\end{array}$ \\
\hline $\begin{array}{l}\text { Allocate the necessary funds to encourage literacy } \\
\text { students in the centers (for example, planning } \\
\text { pilgrimage and tourism camps). }\end{array}$ & $\begin{array}{l}\text { Increase monitoring of the } \\
\text { project }\end{array}$ & $\begin{array}{l}\text { Upgrading the level of } \\
\text { supervision }\end{array}$ \\
\hline
\end{tabular}

According to Table 5, the strategies to strengthen local learning centers include six categories: strengthening the level of participation of individuals and institutions related to the project, improving the level of motivation of individuals and related institutions, improving the quantity and quality of 
educational fields, improving the use of technology, improving the executive bases of the project and improving the level of supervision. Of these categories, three categories (i.e. strengthening the level of participation of individuals and institutions related to the project, improving the level of motivation of individuals and related institutions, and improving the quantity and quality of educational fields) had the highest frequencies, and other components are among the next priorities.

\section{Discussion}

In this study, three basic questions were answered. The findings of the first question indicated that the three categories of environmental harm, motivational harm and organizational harm were the challenges of local learning centers. The two categories of motivational and organizational harms were the most common.

In explaining the results of the first question, it should be acknowledged that special adult education centers, especially government centers such as the literacy movement and learning centers, which are part of the wide Education Organization, have been neglected in recent years. As the findings indicated, among the harms to the performance of these centers were organizational harms including communication, quality of work life, organizational structure, organizational culture, organizational stress, organizational information technology. This part of the research results is consistent with the findings of Mohseni and Hosseini (2015) who have studied the pathology of human resource management in literacy and named the factors of culture and organizational structure as the disadvantages of this field.

On the other hand, in explaining motivational harms including human characteristics, lack of empowerment, lack of staff training, job characteristics, compensation of services, it can be said that education to adults, especially illiterate people, is always challenging due to age, mental and physical stress and busyness. The many daily routines of this special group have caused the lack of motivation of these people to participate in the courses. This part of the results is in line with the findings of Sadeghpour and Hakimzadeh (2016) who investigated the reasons for illiteracy not accepting literacy programs and pointed to the lack of motivational factors and inefficiency and non-application of these trainings.

Also in explaining environmental harms including political factors, economic factors, social factors, environmental factors, and information technology outside the organization, it can be stated that learning centers are among the service centers that are in the context of society and the environment. So, the relationship with the environment is affected by it, and the environment, while being useful, can damage its performance. For instance, inflation causes people to worry about economics instead of science, or the heat of weather conditions causes people to go less to the centers, or the centers are closed in the absence of electricity.

It should be noted that although no research has been done on the title and subject of this study, in general, the results of the current study are in line to the results of Collins's (2011) research which aimed at identifying motivational factors and barriers to adult participation in educational courses, 
Mohseni and Hosseini (2016), regarding the pathology of human resource management in the Literacy Organization, Sadeghpour (2016) on the reasons for illiteracy not accepting basic literacy classes from the perspective of literacy movement instructors and Hakimzadeh, et al. (2015) on the reasons for literacy programs failure.

Regarding the second question, in relation to the opportunities for local learning centers, four key categories were strengthening the cognitive and skill level of the audience and project stakeholders, improving the economic level of the project audience, improving the learning time and improving the level of social support for literacy.

In explaining these findings, it can be said that empowerment and creating an entrepreneurial spirit in learners by participating in vocational training courses and learning new skills should be considered. Establishing the contracts at the provincial level with technical and professional centers for training and providing technical certification for learners has led to the creation of small and high-yield production and economic cooperatives by learners, which help family livelihoods and easier access to employment, as well as economic growth of communities. Participation in basic life skills training courses increases decision-making power, increases the level of awareness and social literacy of learners about social, educational, political, and religious issues, which in turn creates capable and knowledgeable families. Literacy and the audience of local learning centers should have unlimited opportunities for the necessary training in the centers. Participating in the activities and ceremonies of the learning center creates buoyancy and self-confidence in learners, which has a great impact on increasing the quality of their personal and social life, and people will benefit from a better sense of buoyancy and self-confidence in making decisions. Participating newcomers in festivals under any title and from any organ and institution in terms of topics and content of workshops is the best opportunity to unveil the capabilities of the centers. The most important opportunity that learning centers give to learners is lifestyle change, that is, empowering an individual to achieve a wise and purposeful life. Up-to-date general information and expertise of the center's managers, having experienced, active and specialized instructors, providing the required budget and increasing and continuous attention and support of government departments can provide more learning opportunities for learning centers.

Regarding the third question about strategies for improving local learning centers, the research findings showed six categories: strengthening the level of participation of individuals and institutions related to the project, improving the motivation of individuals and related institutions, improving the quantity and quality of educational fields, improving technology, executive bases of the project and upgrading of the supervisory level are strategies to strengthen the level of local learning centers.

This finding indicates that the cooperation of departments such as the Department of Industrial and Mining Labor, Handicrafts, Natural Resources, Municipalities and Government Offices with the literacy movement should be strengthened; Provide support and incentive packages for learners of these centers; Provide intelligent use of new technologies for learners; Hold various festivals about learners' activities; In addition to participating in teaching methods, educators should participate in skills and vocational training courses; The literacy movement should establish contracts with technical and professional 
centers to train and provide technical certification for learners; Supervising and implementing the programs via an executive committee and monthly meeting; Cooling and heating facilities, software and hardware, suitable location and necessary budget to be provided for learning centers.

Based on the research findings, it is suggested that the principals of the literacy movement should anticipate and implement special programs to reduce the harm of learning centers. These programs include training for managers, educators, and literate people to increase their knowledge, selfconfidence, and self-esteem. The directors of the education organization are suggested to pay more attention to the literacy movement in the organizational structure of education and the directors of the literacy movement should pay more attention to the local learning centers. Also, the leaders of the literacy movement should seek help from other organizations and institutions outside the organization to increase the performance of their learning centers. It is suggested that senior managers of the Literacy Movement take measures to improve the level of research in organizations and encourage employees to do research. Among the measures and programs through which the promotion of research in the organization can be provided are: providing facilities such as libraries, archives of specialized journals, etc. as tools of the information system and encouraging employees to do research work, holding the conferences, inviting researchers and professors, holding lectures and presenting the results of the performance of these research institutes to the staff.

Managers of the literacy movement can empower educators to achieve collective insight and help by providing information more quickly and easily, updating the organization, improving the quality of work life, promoting organizational culture, reducing work stress, etc. Eventually, it improves the performance of local learning centers.

Commitment of the management of the education organization to facilitate political, social, economic and economic factors can help reduce the harm and improve the performance of local learning centers by eliminating cumbersome and inefficient laws and regulations.

Interested researchers are recommended to conduct their research separately, taking into account the offices of the literacy movement and different local learning centers in other cities and provinces. Considering the importance of recognizing the effective factors on improving the performance of local learning centers of the literacy movement, it is recommended that individual and family factors, students' emotional intelligence, spiritual intelligence, organizational structure, organizational climate, organizational entrepreneurship, knowledge management, organizational trust and organizational justice be examined and assessed. Moreover, future research can explore the factors affecting the improvement of the quality of education in local learning centers.

Conflict of interest: The authors state no conflict of interest in the study.

Financial sponsor: The authors acknowledge that they have not received any financial support for all stages of the study, writing and publication of the paper. 
Acknowledgment: We hereby appreciate all the participants of the study as well as all those participating in the implementation of this project.

\section{References}

Atashk, M. (2006). 30 years of fighting illiteracy. Plan Journal, (1) 190, 30-27. (Persian). https://www.sid.ir/fa/journal/Reference.aspx?id=162791

Bagherian, F. (2001). The effect of literacy on the attitude of rural women. Women's Research Quarterly, 1, 33-36. (Persian). https://www.sid.ir/fa/journal/ViewPaper.aspx ?id=35835

Barqi, I. (2018). Literacy is a key element of sustainable development, Journal of Development Strategy, 56, 43-57. (Persian). http://rahbord-mag.ir/Articles

Calins, D. (2011). Supporting transfer of training: Effects of the supervisor, Doctoral dissertation, University of Twente, Enschede.

Eskandari, M. (2015). Effectiveness of education, Hemayat newspaper, No. 114, year 10. Tehran: Cultural Research Office. (Persian).

Hadianfard, H. (2019). Examining people's attitudes about popular participation in the implementation and development of adult literacy. Journal of Curriculum Research, 9 (1), 54-74. (Persian). https://www.magiran.com/paper/2039354

Hakimzadeh, R., Ghorbani, H. \& Maleki A. (2015). Investigating the causes of illiteracy in the country's literacy programs, Approach in Management, 9 (84), 76-87. (Persian). http://ensani.ir/fa/article/366018

Kurt, R \& Richard, M. (2018). The Role of Continuing Education and Training in Human Resource Development: An Administrations viewpoint, Journal of Academic Librarianship, 40, 155-151. https://eric.ed.gov/?id=EJ185187

Maykut, P \& Morehouse, R (1992). Beginning Qualitative Research: A Philosophic and Practical Guide, London, The Farlmer Press.

Mohseni, M. and Hosseini, S.S. (2016). Pathology of Human Resource Management in Iran Literacy Organization, the Second National Conference on New Studies and Research in the Field of Educational Sciences and Psychology of Iran. (Persian).

Pirian, G. (2012). The effect of educators' psychological literacy on the desire of literacy students to participate in literacy courses. Tehran: Simaye Danesh. (Persian).

Pourramazan, I., \& Amiri Mikal, M. (2014). Analysis of the role of literacy movement in the cultural development of villages in Guilan province, Geographical perspective in human studies, (9) 26, 5265. (Persian). http://jshsp.iaurasht.ac.ir/article 513748.html

Pouzdenikuda, B .(2019). Evaluation training effectiveness, N.T, Mc Grow. Hill, of Management Learning and Education, 2(4), 386-401. https://core.ac.uk/download/pdf/298087117.pdf 
Rahimi Nejad, V. (2012) A comparative study of the adult education system in the world and presenting the axes of an efficient and effective model for the adult education system. The portal of the Literacy Movement Organization. (Persian).

Sadeghpour, E. (2016). Investigation of the reasons for illiteracy not accepting introductory literacy classes from the perspective of educators of the East Tehran Literacy Movement. Tehran: Iran Literacy Movement Organization. (Persian).

Teymourian, A. (2016). A Study of Comparison of Active Teaching Methods between Literacy Movement Instructors and Graduates of Teacher Training Centers in Primary School, Fifth National Scientific Research Congress on Development and Promotion of Educational Sciences and Psychology. (Persian).

Zakeri, M. \& Sabahizadeh, M. (2020). Identifying the Challenges and Strategies for Improving the Family Literacy Plan: A Case Study of Hormozgan Province. Journal of Research in Curriculum Planning. 66. 184-194. (Persian). http://jsr-e.khuisf.ac.ir/ 